\title{
The Study on the Evolution of Public Trail and the Value of Cultivating Citizen's Legal Consciousness
}

\author{
Wang-Wang HE \\ Northwestern Polytechnical University, Xi'an 710072, PR China \\ hewangwang1028@126.com
}

\begin{abstract}
Keywords: Public Trial, Cultivation of Legal Consciousness, Litigation Activities, Personal Privacy Abstract: Although China's system of socialist laws was formed until 2011, one of the four principles of litigation activities in our country - the principle of public trial, which we already had a deep understanding about it at the beginning of establishing legal system in the $70 \mathrm{~s}$ and $80 \mathrm{~s}$ of the last century. The practice of the principle of public trial has played an important role in fostering the legal consciousness of the parties in the trial, the participants involved in the trial, the audience, even the media and the public that concern about the trial. But we should also see that the public trial carry out in some places with the activities of "get into five" or "get into seven", which damage the personal privacy rights for the defendant especially for the criminal defendants that are convicted, besides, the grass-roots trial activities also increase judicial cost while weaken the judicial self-restraint, and these problems both prompt our country to continue to pay attention to practice when promote the open trial.
\end{abstract}

\section{The Formation of Public Trial Principles}

Accurately speaking, the legal construction in our country began at the third plenary session of 11th CPC central committee in 1978. Based on the spirit of this plenary session, although there were some problems in the laws that approved and the implemented in March 1978, it had formulated the Constitutional Law that based on the principle of "public trial". China gradually formed a series of laws and its representative laws were the three major procedural laws, China formed the initial legal system in terms of the principle of public trial. In this regard, this can be divided into provisions of the Constitutional Law and the provisions of the three procedural laws.

\subsection{The two Constitutional Laws of the Principle of Public Trial since the Reform and Opening Up}

The first half of paragraph 3, clause 41 of the Constitutional Law of 1978 stipulates that "in addition to the special circumstances of the law, the people's court trial cases all need to be carried out in public." As this provision does not use the term "public trial", the meaning of "all need to be carried out in public" is same as "public trial", and there also stipulates the exception of "all need to be carried out in public"-_the special circumstances of the law".

The current Constitutional Law which was adopted in December 1982, states in its first half of clause 125 that "in addition to the special circumstances of the law, the people's court trial cases all need to be carried out in public." Although the current Constitutional Law has been amended four times, the article 125 remained as it was.Thus, our country had a complete understanding of its importance of the principle of public trial when the Constitutional Law was enacted and passed in 1978, and the Constitutional Law was amended frequently after that, the constitutional provisions on the principle of public trial have remained unchanged. The Constitutional Law in which has no word of "public trial", but the meaning of "all need to be carried out in public" is the same as "public trial".

\subsection{The Provisions of the Principle of Public Trial in the three Major Procedural Laws}

\subsubsection{The Provisions on the Civil Procedure Law}

The Civil Procedure Law(trial) that was adopted in March 1982 and promulgated in October 1982 states that "the people's court, in accordance with the provisions of the law, shall apply the systems of the second instance is the final instance, public trial, collegial panel, withdrawal of judicial personnel", this clause takes the "public trial" as one of the four principles of civil action. 
The clause 103 stipulates that "the people's court trial cases all need to be carried out in public in addition to the special circumstance of involving classified confidential information, personal privacy or the law has another provision. And the divorce case can be heard in non-public when the parties applied." The legal clause regulates the exceptions of public trial. There are three situations that the law allows to keep private: the cases of classified confidential information, personal privacy cases and the situation that the law has another provision. There is only one case which can apply non-public trial: the divorce case.

The Civil Procedure Law of 1991, which was adopted in April 1991 and promulgated on the date of adoption, is the first law that regulates civil litigious activities in China since the founding of new China. As for the principle of public trial, it keeps up with the provisions of the Civil Procedure Law(trial) of 1982 and the contents were more richer-"the proofs that involve the state secrets, commercial secrets and personal privacy should keep secret and should not be presented in public trial when need to show in court." The clause 120 stipulates that "the people's court trial cases shall be carried out in public in addition to the special circumstance of involving state secrets, personal privacy or the law has another provision. The divorce case and the case involving state secrets can be trial in non-public when the parties applied." The legal clause has a clear regulation about the exceptions of public trial of the clause 10 of the Civil Procedure Law of 1991, comparing with the Civil Procedure Law of 1982(trial), there is an added statutory non-public situation of personal privacy.

The clause 10, 66 and 120 don't have any change of the Civil Procedure Law which was adopted in October 2007 and implemented in April 2008.The clause 10 has no change which was adopted in August 2012 and implemented in January 2013, and some serial number has changed but the content has no change, namely,clause 66 changed into clause 68 and clause 120 changed into clause 134.

\subsubsection{The Provisions of the Criminal Procedure Law}

The first half of clause 8 of the Criminal Procedure Law, which was adopted in July 1979 and implemented in January 1980, stipulates that "in addition to the special circumstances of this law stipulated, the people's court trial cases all need to be carried out in public." The clause 11, paragraph 1 and paragraph 2 stipulate that"... But the case concerning classified confidential information and personal privacy all shouldn't be heard in public...." The clause 8 and 11 of the Criminal Procedure Law in 1979 has a clear regulation about the principle of public trial and its exceptional situations. Take the public trial as the principle, take non-public trial as the exception. The statutory non-public trial cases include three situations: the case concerning classified confidential information, personal privacy cases and cases of juvenile delinquents that under 16 years of age. There is only one case, as appropriate, take the public trial: cases of juvenile delinquency who is more than the age of 16 but less than the age of 18 .

The Criminal Procedure Law that was amended in March 1996, approved in July 1997 and carried out on the date of its approval, its provision of first half in the clause 11 is the same as first half in the clause 8 of the Criminal Procedure Law in 1979. Its content of clause 152 is exactly the same as the clause 11 of the Criminal Procedure Law in 1979. Besides, its content of clause 163, paragraph 2 is also the same as the clause 121, paragraph 2 of the Criminal Procedure Law in 1979.

The first half of the clause 11 of Criminal Procedure Law which was approved in March 2012 and carried out in January 2013, is exactly the same as the first half of the clause 11 of Criminal Procedure Law in 1996 and the first half of the clause 8 of Criminal Procedure Law in 1979. The clause 183, paragraph 1 was amended according to the clause 152, paragraph 1 of Criminal Procedure Law in 1996(namely, the clause 11, paragraph 1 of Criminal Procedure Law in 1979) :"The trial case of a first instance of the people's court shall be carried out in public. But the case concerning state secrets and personal privacy shouldn't be heard in public; the case involving commercial secrets can be trial in non-public when the parties applied." There have added a non-public discretionary circumstance: the case concerning commercial secrets. The clause 274 was amended according to the clause 152, paragraph 2 of criminal procedure law in1996(namely, the 
clause 11, paragraph 2 of Criminal Procedure Law in 1979) :the first half part stipulates that" the case shouldn't be trial in public when the defendant is under 18 years old." This provision is better to protect the juvenile defendant's personal privacy. However, the clause 183, paragraph 2 keeps accordance with the clause 152, paragraph 3 (namely: the clause 11, paragraph 3 of Criminal Procedure Law in 1979). And the clause 196 is also the same as the clause 163, paragraph 1 of Criminal Procedure Law in 1996 and the clause 121, paragraph 1 of Criminal Procedure Law in 1979.

\subsubsection{The Provisions of the Administrative Procedure Law}

The clause 6 of the Administrative Procedure Law which adopted in April 1989 and passed October 1990, stipulates the principle of public trial is one of the four principles when the courts hear administrative cases. The clause 54 stipulates that "the people's court should hear the administrative cases publicly, except for cases that concerning state secrets, personal privacy and the law has another provision, and cases involving commercial secrets can be non-public trial when the parties applied." We can see that the non-public trial cases include three situations: the case concerning state secrets, personal privacy cases and the law has another provision. There is only one case of discretionary circumstance of non-public trial: a case involving commercial secrets.

By concluding the historical evolution about the provisions of public trial principle in the Constitutional Law and the three major procedure laws, which are the Civil Procedure Law, the Criminal Procedure Law and the Administrative Procedure Law, we can see that there is a full understanding of the importance of the principle of public trial at the beginning of reform and opening up.We can say that the implementation of the principle of public trial produces today's situation of legal consciousness, although some persons' consciousness of rule of law is still relatively weak, no one can deny the importance of the legal consciousness easily. Because "it still needs many factors make efforts together, especially for common consciousness of rule of law of people, when the society become the actual society with rule of law and the law become people 's beliefs and backer."[1]

\section{The Public Trial Effect on Cultivation of People's Consciousness of "Rule of Law"}

The clause 24, paragraph 1 in the Constitutional Law stipulates that "the state through... the education of legal system, and strengthen the construction of socialist spiritual civilization." Although the "legal system" is "rule of law" here, "legal system" is the prerequisite of the "rule of law", so it also benefits to" the education of rule of law" and the formation of the consciousness of rule of law when we promote the "the education of legal system." "It not only can provide a better social order for governing a country, but also promotes the formation of more advanced social order of "rule of law" when the "rule of law" has penetrated into the way of life of citizens and has coordinated the social relations."[2]

The clause 2 of the Civil Procedure Law provides that one of the tasks of the Civil Procedure Law is "to educate citizens to abide by the law consciously", and the clause 2 of Criminal Procedure Law has the same provision. There is no such a provision in the Administrative Procedure Law, but it is apparent that it can help to educate the people of abiding the law during the administrative litigation activities. It is no doubt that the court implements the principle of public trial will benefit to the education of complying with law of people as well as the cultivation of people' consciousness of "rule of law". Therefore, it plays a basic role in the operation of rule of law to reconstruct and foster people's consciousness of "rule of law", and arouse the mass faith and emotion of the "rule of law". I think the principle's promotion effects of people's consciousness of "rule of law" are in the following four aspects:

First, the scope and name of the subject is different in different litigation activities, even if there is in the same litigation, the names of the participants may be changed between the first instance and second instance, while there must be a couple of "litigation opponents" in each litigation that have a profound impact on the proceedings. According to the provisions of the litigation law, the person who experiences personally the whole process of litigation activities, which not only has an 
opportunity to know all litigation steps, but also can come into contact with the substantive law that concerned. And it will definitely play the positive effects for the cultivation of the consciousness of "rule of law". The defendant who is even in the criminal proceedings, he or she doesn't keep a complete passive participation in litigation activities, however, he or she will take the defending right actively to protect their rights and interests. And it is precisely a way of learning the laws when he or she takes measures to learn the laws that related to the case during the process of litigation activities.

Second, the staff who exercises the public power during the process of litigation activities, such as judges, clerks, prosecutors and even the bailiffs which maintain the court order. In addition, the defendants who appear in court for administrative proceedings, which is representing the administrative subject to carry out the administrative behaviors and he or she should also be considered as exercising the duty of public officer. No matter what identity they are, they have a common identity which is the staff of the state organ. Their every word and action both represent their own legal literacy and the image of the organs of state power, which can make them carefully exercise their powers and continuously strengthen their consciousness of "rule of law". Because the public trial is the principle, the non-public trial is the exception which the laws have already made clear provisions for it. And their every word and behavior maybe spread out with the process of trial when they are in the face of the unspecific audiences and the mediums, according with laws, which have the right to interview. This measure of judicial opening can precisely make the person who masters the public power speak and act cautiously, participate in litigation activities legally and urge them to positively bear the legal duty. In order to realize targets, it is necessarily to learn the law and strengthen their consciousness of rule of law.

Thirdly, except for the first and second kinds of participants, there are including other subjects, such as the witnesses, the defenders, the appraisers, the criminal litigation subjects with the civil litigation, the third parties with or without independent claims and so on during the litigation activities. They do not necessarily have a connection of interest with others, but they play an important role in the advancement of litigation activities. According to the provisions of the law and the proceedings of trial, these participants should accept the command of collegiate bench and explain their views on the case of controversy in a way of initiative or passivity. In order to avoiding the violations of the law, they have to understand and pay attention on the relevant legal provisions and this is a process of strengthening the consciousness of "rule of law". Therefore, "the people will owe the laws only when they experience the effectiveness of the laws so that they will recognize the authority of the laws; the people will increase their faith of the laws only when they understand the function of the laws; the people will protect the laws and cherish the rule of law only when they recognize the value of the laws." ${ }^{[3]}$

Fourthly, because we take the public trial as the principle and take the non-public trial as the exception in our country, so the mediums that concentrate on the litigation activities and the unspecific people can report, disseminate and discuss the case and the scholars can make the analysis or criticism about the case while the public opinion has no power to ask the court to judge or rejudge the case according to their own claims. However, with the development of modern media, a typical case can grab the public attention when it spreads quickly within a short time. And this has two sides for the court work, the advantage is that it is beneficial to spread legal knowledge and foster the consciousness of rule of law in the whole society which it can expose the every stage the trial activities and the court will take measures to respond for the criticism of public opinion and social concerns. And it also contributes to the restriction of judicial corruption, makes people to understand the handling process of the court, reduces the bad reputation of the innocent court and finally win public faith when carry out the judicial opening.

\section{Some Reflections on the Implementation of the Current Public Trial Principle}

The public trial has been implemented since it was written into the Constitutional Law and the laws which promotes judicial opening, prevents judicial corruption and provides a precious 
opportunity for public to understand the litigation process and the relevant legal knowledge.But we should also realize that there are still some problems that need to be pay attention when we implemented the principle of public trial in our county. If we ignore these issues intentionally, it may have some negative effects for the functions of the public trial, and I think there are two main problems:

Firstly, the defendant of criminal proceeding probably is in the most disadvantaged position on process of the three litigation activities. There are defendants in civil proceedings and administrative proceedings, even if they lose the case, the consequence for the defendant is not as serious as the defendants who are in criminal proceedings. Because the defendants who are in criminal proceedings once bring in guilty, their freedom and even their life may be deprived. However, except for punishing the losing party, the trial should also be based on the balance of the principle of punishment and education so that the trial can try its best to protect the legitimate rights and interests of the losing party. Nowadays, it often takes the way of live streaming when the court is on the hearing process of major cases and this is a practice of public trial. But in this process, it is rarely to take measures to blur the defendant's face which is on suspicion of leaking the defendant's personal privacy. The reason why we think so is that"they are entitled to basic human rights for the people who are the parties involved in the legal relationship of criminal proceedings or the people who are participate in the relevant criminal proceedings. The privacy as a basic human rights, it is protected by law and the defendant as the participants, should been entailed the right of privacy. "[4]

Secondly, chasing the judicial opening blindly and making justice get into the people's life excessively will weaken the judicial self-restraint which the justice should have. Shaanxi Province is one of the provinces that promoted earlier about the court's activities of "get into five" activities(into the countryside, communities, enterprises, schools and barracks). The several cities in Heilongjiang Province also launched the "get into seven"(in addition to the communities, schools and enterprises, there are getting into the organs, the villages, the units, the barracks) activities, which have the suspicion of "campaign-style law enforcement" or "mass-style trial". Since the court has a fixed place of trial, it should be in a fixed place to carry out trial activities rather than change the trial site endlessly to other non-specific place. There are two reasons for this: On the one hand, except for the exceptions that provided by law, most of cases are in public trial. But the court space is limited that cannot accommodate too many audiences, which restricts more people to know the case in a disguised form. Actually, this is a kind of protection for the reputation of the losing party. After all, it will bring adverse interference for the people who will return to society in future or for the families' peaceful life when the trial result of the unsuccessful party, especially the defendant in the criminal proceedings, get spread everywhere. On the other hand, whether they are "get into five" activities or "get into seven" activities, when they get implemented, the court should prevent the agitated crowd to break the order of the trial, and there will need relevant organizations organize the public to audit the trial, even the judge will need to speak loudly. In the process of the criminal proceedings, the defendants that arrested should be sent to the trial site, this will increase the judicial costs of getting into the grass-roots level. Therefore, despite the original intention of the "get into five" or "get into seven" activities is good, but it should also take the judicial self-restraint and the reality of economizing judicial cost into consideration and it should take a more pragmatic attitude to consider the principle of trial opening and its practice.

In short, our country has already taken the public trial as one of the four core principles of litigation when we constructed the socialist legal rule system at the beginning of reform and opening up. We also already have a deep understanding of what situation should be taken into the exception when we formulated the three major laws, namely, the Civil Procedure Law, the Criminal Procedure Law and the Administrative Procedure Law in the last century. And the relevant legal provisions is relatively perfect, despite there are several modifications in the current constitution and the three major litigation laws, the principle of the public trial just have slight refinement. Since the implementation of the principle of open trial, it has played a positive role in the cultivation about the consciousness of rule of law for the parties, the participants in the litigation activities and 
the media and even the ordinary populace.However, in addition to punishment, the trial should have the effects of education and influence for the losing party, and can make the person realizes the importance of abiding laws. It is his or her own business whether the person has realized the importance or not, the judicial organ should try its best to do it. So it should be pragmatic in carrying out the principle of the public trial while cannot weaken the judicial self-restraint. So that it can serve better for the parties and other participants in the litigation activities and can even serve for the cultivation of consciousness of the rule of law in the whole society. And our country's construction of rule of law can have an initial achievement when there is the consciousness of "the authority of the law is derived from the people's inner support and sincere faith." ${ }^{[5]}$

\section{References}

[1] Jing-shan Dong:"traditional ethics - the first factor to develop the people's consciousness of the rule of law ", "Lanzhou Journal" No.6, 2014.

[2] Zhen-qing Ma:"the cultivation of the people's recognition and the abilities of the rule of law in national governance system ", "ideological and political education research" No.5, 2014.

[3] Dan-bo Xia:"the study on the main content of people's consciousness of the rule of law", "the journal of Guizhou Normal University" No.8,2016.

[4] Shu-yang Qu:"the persistence of the principle of public trial in criminal justice and the upgrade of defendant's privacy protection ", "Journal of Xiang-tan University (the version of philosophy and social sciences)" No.5, 2016.

[5]"The fourth plenary session of the eighteenth central committee of the CPC", "People's Daily", October 24, 2014. 